\title{
PENINGKATAN KEAKTIFAN MAHASISWA PADA PEMBELAJARAN PENGEMBANGAN MEDIA MANIPULATIF MELALUI STRATEGI SNOWBALL THROWING
}

\author{
Tatik Retno Murniasih \\ Dosen Pendidikan Matematika Universitas Kanjuruhan Malang \\ Email: tretnom@yahoo.com
}

\begin{abstract}
Abstrak
Tujuan dari penelitian ini adalah mendeskripsikan langkah-langkah penerapan strategi snowball throwinguntukmeningkatkan keaktifan mahasiswa pada pembelajaran pengembangan media manipulatif. Subyek penelitian adalah mahasiswa Prodi Pendidikan Matematika kelas 2012B sebanyak 20 orang.Penelitian ini adalah Penelitian Tindakan Kelas yang terdiri dua siklus, tiap siklus terdiri dari empat tahapan yaitu perencanaan, pelaksanaan, pengamatan dan refleksi. Data yang diperoleh berupa nilai persentase peningkatan keaktifan pada akhir siklus I dan pada akhir siklus II. Hasil penelitian menunjukkan peningkatan keaktifan mahasiswa. Peningkatan keaktifan mahasiswa dapat dilihat dari meningkatnya indikator keaktifan mahasiswa pada siklus I dan II. Selain itu hasil tes akhir mahasiswa yang menenuhi kriteria keberhasilan juga mengalami peningkatan pada siklus Isebesar 65\% meningkat menjadi $90 \%$ pada siklus II.Berdasarkan kriteria keberhasilan disimpulkan bahwa penerapan strategi pembelajaran snowball throwing dalam pembelajaran pengembangan media manipulatif dapat meningkatkan keaktifan mahasiswa.
\end{abstract}

\section{Kata-kata Kunci: keaktifan, media manipulatif, snowball throwing}

\begin{abstract}
The purpose of this study aredescribe the steps snowball throwing strategy implementation for increasing the activity of students in the learning development of manipulative media. Subjects were students of class 2012B Mathematics Education Prodi as many as 20 people. This research is a Classroom Action Research that consists of two cycles, each cycle consisting of four phases: planning, act, observe and reflection. Data obtained in the form of a percentage increase in the value of the activity at the end of the first cycle and at the end of the second cycle. The results showed an increase in the activity of the students. Increased activity of students can be seen from the increased activity of students in cycle indicators I and II. In addition the results of the final tests student success criteria also increased in the first cycle by $65 \%$ rising to $90 \%$ in the second cycle. Based on the success criteria is concluded that the application of learning strategies snowball throwing in the learning development of manipulative media can enhance the activity of the students
\end{abstract}

\section{Keywords: liveliness, manipulative media, snowball throwing}

Berdasarkan hasil observasi pada tanggal 11 Pebruari 2015 yang dilakukan terhadap kelas 2012B Prodi Pendidikan Matematika Universitas Kanjuruhan Malang terlihat mahasiswa cenderung pasif selama pembelajaran. Ada dua penyebab pasifnya mahasiswa dalam perkuliahan yaitu: (1) dalam menyampaikan materi dosen tidak melibatkan mahasiswa, dan (2) mahasiswa kurang siap dalam menerima materi pelajaran.
Peran aktif mahasiswa dalam belajar sangat penting. Menurut Silberman (2006), guru hendaknya dapat mengaktifkan siswa dalam belajarnya, karena belajar memerlukan keterlibatan mental dan kerja siswa itu sendiri. Sardiman, A.M. (2007), mengatakan bahwa aktivitas siswa tidak hanya mendengarkan dan mencatat saja, akan tetapi aktivitas siswa dapat digolongkan menjadi: (1) visual activities, (2) oral activities, (3) listening activities, (4) writing activities, (5) drawing activities, 
(6) motor activities, (7) mental activities, dan (8). emotional activities. Untuk itu diperlukan pembelajaran aktif yang melibatkan fisik dan mental mahasiswa.

Salah satu strategi pembelajaran yang dapat membangkitkan keaktifan mahasiswa adalah snowball throwing. Dengan model pembelajaran melalui tipe ini diharapkan keaktifan mahasiswa semakin meningkat. Menurut Ismail (2008),snowball berarti bola salju, sedangkan throwing artinyamelempar. Snowball throwing dapat diartikan melempar bolasalju. Dalam pembelajaran snowball throwing, bola salju merupakan kertas yangberisi pertanyaan yang dibuat oleh siswa kemudian dilempar kepada temannya sendiriuntuk dijawab. Model snowball throwing merupakan pembelajaran kooperatif yangdalam pelaksanaannya banyak melibatkan mahasiswa. Peran dosen hanya sebagai pemberi arahan awal mengenai topik pembelajaran danselanjutnya penertiban terhadap jalannya pembelajaran. Menurut Asrori (2010), pembelajaran snowball throwing memberikan beberapa manfaat salah satunya adalah dapat meningkatkan keaktifan belajar. Mahmood, dkk (2011) dalam penelitiannya membahas masalah inti pembelajaran dan menawarkan strategi untuk belajar aktif sebagai alternatif pembelajaran pasif.

Dari hasil observasi awal dan beberapa pendapat ahli maka peneliti tertarik untuk menggunakan strategi snowball throwing untuk meningkatkan keaktifan mahasiswa pada pembelajaran media manipulatif di kelas 2012B Prodi Pendidikan Matematika Universitas Kanjuruhan Malang.

\section{Metode Penelitian}

Dalam penelitian ini peneliti menggunakan Penelitian Tindakan Kelas (PTK) model Kemmis dan McTaggart. Pada model Kemmis dan McTaggart satu siklus terdiri dari empat komponen, yaitu: perencanaan, tindakan, pengamatan dan refleksi. Penelitian ini dilaksanakan di Prodi Pendidikan Matematika Universitas Kanjuruhan Malang. Penelitian dimulai 11 Pebruari2015 sampai dengan 22 April 2015. Mahasiswa yang dijadikan subjek adalah mahasiswa kelas2012B. Jumlah mahasiswa yang terdapat pada kelas 2012B yaitu 20 orang terdiri dari 14 siswa perempuan dan 6 siswa lakilaki.Kegiatan dalam penelitian ini bertujuan untuk meningkatkan keaktifan mahasiswa pada pokokbahasan pengembangan media manipulatif melalui strategi snowball throwing.

Peneliti menggunakan beberapa cara untuk mengumpulkan data tentang peningkatan keaktifan mahasiswa pada pembelajaran pengembangan media manipulatif melalui strategi snowball throwing, diantaranya: (1) dokumentasi berupa foto kegiatan pembelajaran, (2) lembar pengamatan selama pembelajaran untuk mencari data keaktifan mahasiswa selama pembelajaran, (3) wawancara untuk menelusuri peningkatan keaktifan mahasiswa, dan (4) catatan lapangan untukmelengkapi data yang tidak terekampada lembar pengamatan keaktian mahasiswa.

Data yang dianalisis, yaitu: (1) analisis hasil tes mahasiswa, dan (2) analisis hasil pengamatanindikator keaktifan mahasiswa. Analisis data dilakukan untuk mengetahui keaktifan mahasiswa berupa tes hasil belajar dan hasil observasi terhadap indikator keaktifan mahasiswa. Analisis hasil belajar dilakukan dengan mengamati lembar jawaban mahasiswa untuk menelusuri dan menganalisis kesulitan atau kesalahan mahasiswa. Dengan cara ini akan diketahui sudah tercapai atau belum kriteria keberhasilan yang telah ditentukan. Setelah rekap tes akhir diperoleh, nilai dikonversi dalam rentang $0-100$ dengan rumus:

$$
\mathrm{S}=\frac{T}{M} \times 100 \%
$$


Keterangan:

$\mathrm{S}=$ skor

$\mathrm{T}=$ skor tes akhir mahasiswa

$\mathrm{M}=$ skor maksimal tes akhir mahasiswa
Indikator pengamatan keaktifan mahasiswa dapat dilihat pada table di bawah ini:

Tabel 1. Indikator Keaktifan

\begin{tabular}{l}
\hline \multicolumn{1}{c}{ Indikator } \\
\hline Kemampuan mahasiswa dalam bertanya \\
\hline Kemampuan mahasiswa dalam memberikan \\
kritik/masukan yang membangun \\
\hline $\begin{array}{l}\text { Kemampuan mahasiswa dalam menjawab } \\
\text { pertanyaan }\end{array}$ \\
\hline Kemampuan mahasiswa dalam \\
mempresentasikan hasil kerja di depan kelas \\
\hline $\begin{array}{l}\text { Kemampuan mahasiswa dalam mengerjakan } \\
\text { soal di depan kelas }\end{array}$ \\
\hline
\end{tabular}

Kriteria yang digunakan untuk menentukan hasil pengamatan indikator keaktifan yaitu:

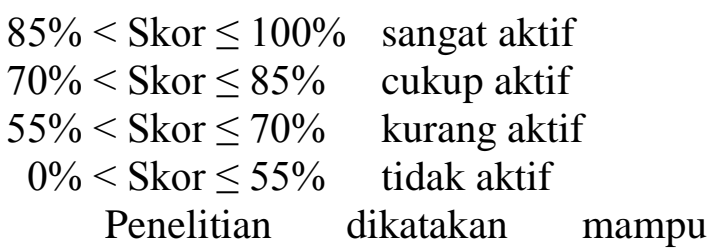
meningkatkan keaktifan mahasiswa jika: (1) $75 \%$ hasil tes akhir mahasiswa memenuhi nilai minimal 80 , dan (2) hasil pengamatan indikator keaktifan mahasiswa minimal pada kategori cukup aktif.

Teknik pengecekan keabsahan data yang dilakukan menggunakan tiga cara, yaitu: (1) teknik pengecekan ketekunan pengamat, (2) triangulasi, pemeriksaan teman sejawat (Sugiyono, 2008). Ketekunan pengamat dilakukan dengan kehadiran peneliti pada proses pembelajaran berlangsung. Peneliti mengadakan pengamatan dengan teliti dan rinci secara mendalam. Peneliti juga melakukan wawancara terhadap siswa yang mengalami kesulitan dan wawancara tentang pembelajaran. Menurut Moleong (2004) triangulasi adalah teknik pemeriksaan keabsahan data yang memanfaatkan sesuatu yang lain di luar data itu untuk keperluan pengecekan atau sebagai pembanding terhadap data itu. Triangulasi yang digunakan dalam penelitian ini adalah triangulasi sumber dan triangulasi metode. Pemeriksaan teman sejawat yang dimaksudkan di sini adalah mendiskusikan hasil penelitian dengan sesame dosen Prodi Pendidikan Matematika.

\section{Hasil Penelitian dan Pembahasan}

Pada siklus I materi yang dipelajari tangram dan persamaan linier satu variabel. Sedangkan siklus II materi yang dipelajari adalah segitiga dan phytagoras. Pertemuan I dimulai pada tanggal 25 Pebruari 2015. Pembelajaran dimulai dengan salam, doa dan mengabsen mahasiswa. Dosen menanyakan tentang tujuan pembelajaran yaitu melalui strategi snowball throwing pada pembelajaran media manipulatif mahasiswa dapat memahami tentang tangram. Dosen memberikan apersepsi tentang materi prasyarat yang harus dikuasai mahasiswa.

Langkah-langkah pembelajaran padapertemuan I dengan strategi snowball throwing adalah: (1)Dosen 
menyampaikan materi yang akan disajikan. Dosen membentuk kelompokkelompok dan memanggil masingmasing ketua kelompok untuk memberikan penjelasan tentang materi.
Materi pertemuan 1, pada siklus I yaitu tangram dapat dilihat pada gambar di bawah ini:

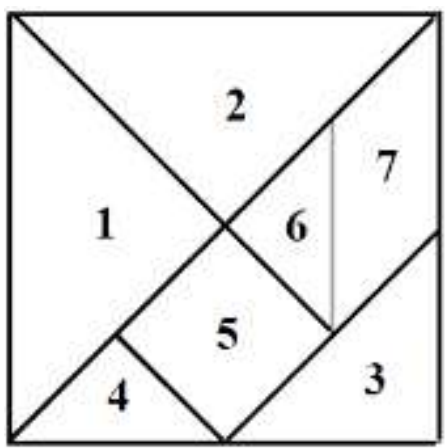

Gambar1.Tangram

Dosen memberikan kepada ketua kelompok berupa peralatan untuk membuat media seperti gambar 1 , antara lain: kertas lipat, penggaris,lem, gunting, pines dan styrofoam.

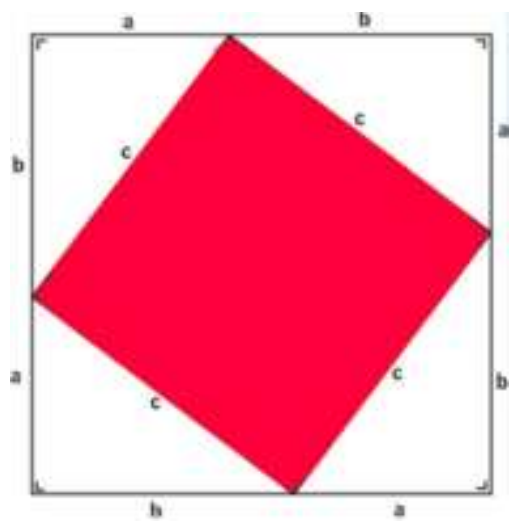

Gambar 2. Phytagoras
Dosen memberikan kepada ketua kelompok berupa peralatan untuk membuat media seperti gambar 2, antara lain kertas lipat, penggaris, lem, gunting, pines dan styrofoam.

(2) Masing-masing ketua kelompok kembali ke kelompoknya kemudian menjelaskan materi yang disampaikan oleh dosen kepada temannya,

Kemudian masing-masing mahasiswa diberikan satu lembar kerja untuk menuliskan pertanyaan apa saja yang
Materi pertemuan 1, pada siklus II yaitu Phytagoras dapat dilihat pada gambar di bawah ini 
Beberapa pertanyaan mahasiswa berkaitan dengan tangram yaitu:

a. Ada berapa banyak potongan 1 dan 2 untuk dapat membuat persegi?

b. Ada berapa banyaknya potongan 1 dan 2 untuk dapat membuat belah ketupat

c. Manakah potongan yang kongruen dan sebangun?

d. Potongan 4 dan 6 dapat membentuk bangun yang sebangun dengan potongan berapa?

e. Potongan 1 dan 2 dapat membentuk bangun yang sebangun dengan potongan berapa?

Beberapa pertanyaan mahasiswa berkaitan dengan Phytagoras yaitu:

a. Berapakah luas daerah yang berwarna merah? b. Berapakah luas daerah satu segitiga siku-siku?

c. Berapakah luas daerah empat segitiga siku-siku?

d. Berapakah luas daerah persegi dengan panjang $(a+b)$ dan lebar $(a+$ b)?

e. Berapakah luas daerah persegi yang berwarna merah sebagai selisih luas persegi dengan panjang $(a+b)$ dan lebar $(\mathrm{a}+\mathrm{b})$ dengan luas daerah empat segitiga siku-siku?

(6) Evaluasi, dan (7) Penutup.

Berdasarkan hasil penelitian didapatkan tes hasil belajar mahasiswa pada siklus I dan siklus II yaitu:

Data tes hasil belajar dapat dituangkan dalam grafik seperti di bawah ini:

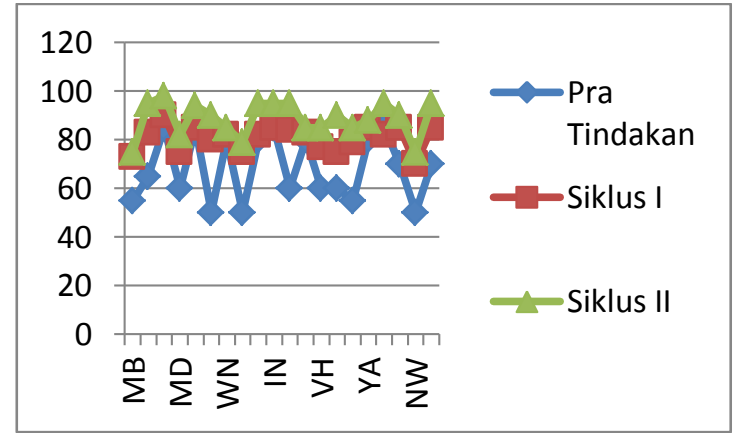

Gambar 3. Grafik tes hasil belajar mahasiswa

Grafik pengamatan keaktifan mahasiswa

dapat dilihat pada gambar 4 .

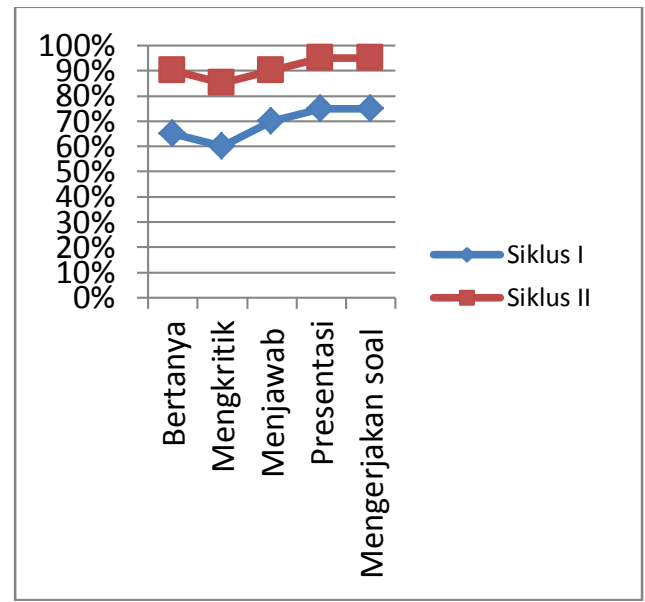

Gambar 4. Pengamatan Keaktifan Mahasiswa 
$\begin{array}{rrr}\text { Kegiatan } & \text { pada } & \text { pembelajaran } \\ \text { pengembangan } & \text { media } & \text { manipulatif }\end{array}$ melalui strategi snowball throwing dapat meningkatkan keaktifan mahasiswa. Hal ini dapat dilihat dari data siklus I dan II yang mengalami peningkatan. Strategi snowball throwing dapat menjadikan mahasiswa lebih aktif. Sesuai dengan penelitian Yahya (2014), mengatakan bahwa penerapan model pembelajaran snowball throwing membuat siswa lebih bersemangat dalam belajar karena guru memberikan kesempatan kepada siswa untuk mengekspresikan pendapatnya secara bebas dan siswa dapat menyumbang pikirannya untuk memecahkan masalah bersama.Menurut Sukertiasih (2010), penerapan snowball throwing dapat meningkatkan prestasi belajar di SMA Saraswati Mataram dengan aktivitas siswa telah mencapai kategori sangat aktif.

\section{Simpulan}

Pembelajaran pengembangan media manipulatif melalui strategi snowball throwing terdiri atas langkah-langkah berikut: (1) Dosen menyampaikan materi yang akan disajikan. Dosen membentuk kelompok-kelompok dan memnggil masing-masing ketua kelompok untuk memberikan penjelasan tentang materi, (2) Masing-masing ketua kelompok kembali ke kelompoknya kemudian menjelaskan materi yang disampaikan oleh dosen kepada temannya, (3) Kemudian masing-masing mahasiswa diberikan satu lembar kerja untuk menuliskan pertanyaan apa saja yang menyangkut materi yang sudah dijelaskan oleh ketua kelompok, (4) Kemudian kertas tersebut dibuat seperti bola dan dilempar dari satu mahasiswa ke mahasiswa lain selama kurang lebih 15 menit, dan (5) Setelah mahasiswa mendapat satu bola/satu pertanyaan diberikan kesempatan kepada siswa untuk menjawab pertanyaan yang tertulis dalam kertas berbentuk bola tersebut secara bergantian, (6) Evaluasi, dan (7) Penutup.

Penerapan strategi snowball throwing pada pembelajaran pengembangan media manipulatif menunjukkan keaktifan mahasiswa.Hal ini dapat dilihat pada indikator: (1) kemampuan mahasiswa dalam bertanya pada siklus I 65\% dan siklus II 90\%, (2) kemampuan mahasiswa dalam memberikan kritik/masukan yang membangun pada siklus I $60 \%$ dan siklus II $85 \%$ (3) kemampuan mahasiswa dalam menjawab pertanyaan pada siklus I $70 \%$ dan siklus II 90\% (4) kemampuan mahasiswa dalam mempresentasikan hasil kerja di depan kelas pada siklus I $75 \%$ dan siklus II 95\% dan (5) kemampuan mahasiswa dalam mengerjakan soal di depan kelas pada siklus I 75\% dan siklus II 95\%. Selain itu hasil tes akhir mahasiswa yang menenuhi kriteria keberhasilan pada siklus I sebesar $65 \%$ meningkat menjadi $90 \%$ pada siklus II. Berdasarkan uraian tersebut dapat disimpulkan bahwa pembelajaran pengembangan media manipulatif melalui strategi snowball throwing dapat meningkatkan keaktifan mahasiswa Prodi Pendidikan Matematika Kelas 2012B UniversitasKanjuruhan Malang.

\section{Pustaka Rujukan}

A.M., Sardiman. 2007. Interaksi dan Motivasi Belajar Mengajar. Jakarta: PT. Raja Grafindo Persada.

Alternative To Passive Learning. Academic Research International. Volume 1. Nomor 3.

Asrori. 2010. Penggunaan Model Belajar Snowball Throwing dalam Meningkatkan Keaktifan Belajar. Yogyakarta: Pustaka Pelajar.

Isjoni dan Arif Ismail. (2008). Modelmodel Pembelajaran Mutakhir. Yogyakarta: Pustaka Pelajar. 
Mahmood, Muhammad Asim, dkk. 2011. Strategies For Active Learning: An

Moleong, Lexy. J. 2004. Metode Penelitian Kualitatif. Bandung: Remaja Rosdakarya.

Silberman, Melvin L. 2006. Active Learning: 101 Cara Belajar Siswa Aktif. Bandung: Nusamedia.

Sugiyono. 2008. Metode Penelitian dan Pendidikan. Surakarta: Mata Padi Pressindo.

Sukertiasih. 2010. Implementasi Pembelajaran Kooperatif dengan Metode Snowball Throwing pada Pokok Bahasan Limit Fungsi untuk Meningkatkan Aktivitas dan Prestasi Belajar Siswa Kelas XI IPA SMA Saraswati Mataram Tahun Ajaran 2007/2008. Jurnal Ganec Swara Volume 4. No. 1.

Yahya. 2014. Penerapan Model Pembelajaran Snowball Throwing dalam Meningkatkan hasil BelajarSiswa SMA Negeri 1 Sigli. Jurnal Sains Riset Volume 4. No. 1. 